\title{
Placental therapy: An insight to their biological and therapeutic properties
}

\author{
Shing Yi Pan ${ }^{1 *}$, Mike K.S. Chan ${ }^{1,2}$, Michelle B. F. Wong',2, Dmitry Klokol ${ }^{*}$ and Vladymyr Chernykh ${ }^{1}$ \\ ${ }^{1}$ Stellar Biomolecular Research, Germany \\ ${ }^{2}$ Fetal Cell Technologies International, Europe
}

\begin{abstract}
The placenta, supporting the growth and development of the fetus, are rich in amino acids, peptides, vitamins, trace elements and growth factors, nutrients and biological active components. Placental therapy was applied to promote from the recovery of diseases and tissue regeneration since the early 1900 s. Since then, placental therapy was applied in various clinical applications as they were shown to exhibit remarkable therapeutic attributes ranging from anti-oxidant, antimicrobial, anti-inflammatory, pain reduction, hair growth promotion, health improvement, cellular proliferation, tissue regeneration and wound healing properties in vivo. This review further summarizes the historical aspects, cellular mechanism, nutrient content and therapeutics properties of the placenta.
\end{abstract}

\section{Introduction}

The placenta is a vascular organ with a known duration of life and it is only developed with the occurrence of pregnancy. It attaches to the uterine wall and the umbilical cord which connects between the mother and the fetus, thus supporting the growth and development of the fetus [1]. The word placenta derives from the Greek word "plakoenta" meaning "Flat Cake", with a flat, round or oval shape appearance, with the outermost and innermost membrane known as the chorion and the amnion respectively $[2,3]$.

During pregnancy, they play an important role in the transfer of gases, nutrients, removal of waste products, which is vital for the life sustenance of the fetus [4,5]. It functions as a temporary endocrine gland, which secretes both peptide and steroid hormones to maintain pregnancy, parturition, lactation and fetal development [6]. Also, the placenta serves as a natural storage centre of many biologically active components ranging from enzymes, amino acids, peptides, polydeoxyribonucleotide (PDRN), vitamins, trace elements, growth factors with significant immunomodulatory, anti-inflammatory and wound healing activities [7-9].

The structure of human placenta and sheep placenta varies as fetal components of the sheep placenta are classified as epitheliochorial, villous with cotyledonary structure. The sheep placenta is formed by the attachment of the chorionic membrane to the caruncles (maternal side of the placenta) on the uterine walls 20-30 days of pregnancy. These points of attachment develop into placentomes which facilitates the transfer and exchange of gases, nutrients and waste products removal $[2,10]$.

In humans, the placenta is a haemochorial placenta with flat, disc shape and with tissue layers separating the maternal and fetal blood streams. The umbilical cord inserts roughly at the centre of the chorionic plate, which give rise to the chorionic villi. The chorion can be divided in to two cellular layers: 1) the outer syncytiotrophoblast and 2) the inner cytotrophoblast. As pregnancy proceeds, there is a marked reduction in the cytotrophoblast layer. Transportation of substances across the placenta is greatly regulated by the basal membrane and the syncytiotrophoblast. All materials and substances pass through the intervillous spaces through the syncytiotrophoblast, then to the fetal connective tissues and into the fetal capillaries and lastly into the fetal blood $[4,11,12]$.

In terms of the biochemical content of the placental tissue, there is no significant difference across various species. Since 30 years ago premium range of supplements containing nutrients of placenta were formulated and produced under the MFIII brand. In present, the current generation of supplements in a form of softgels is widely known and used worldwide as "PE Advanced Formula". The choice of sheep as a source of placenta is justified by high safety standards, absence of cultural and religious taboos against this species and its extraordinary nutritious qualities.

Placentophagy or placentophagia refers to the postpartum ingestion of whole placenta after childbirth. However, placentophagy refers to the consumption of placenta by humans while placentophagia refers to the consumption of placenta and amniotic fluid by most mammals including herbivores and primates [1,13]. Nonetheless, maternal placentophagy are not a common practice in humans whereas they are variously regarded as a biomedical waste and are dispatched based on their cultural, societal, personal or religious beliefs $[6,14]$.

Based on previous literatures in the 1960s, midwives and obstetrical nurses of Chinese and Thai origin residing in the North Vietnam consumed fried placenta served with onions obtained from young,

Correspondence to: Shing Yi Pan, Stellar Biomolecular Research UG An der Welle 4, 60322 Frankfurt am Main, Germany, E-mail: patricia.pan@microsuisse.com

Dmitry Klokol, Stellar Biomolecular Research UG An der Welle 4, 60322 Frankfurt am Main, Germany, E-mail: dr.dmytro@sbi-europe.com

Key words: placenta, fetus, amino acids, placental therapy

Received: August 10, 2017; Accepted: September 12, 2017; Published: September 16, 2017 
healthy and attractive mothers from Hospital in Haiphong, Vietnam [15]. In the early 1970s, human maternal placentophagy were promoted in small number of women in the United States and Mexico as they contained diverse bioactive compounds with therapeutic benefits [16]. Placenta consumption were able to support and replenish nutrients and hormones to the mother which were lost after parturition [14].

The placenta could be served raw, cooked or encapsulated and to be taken as supplements as it contains various nutritional benefits. Previous reports stated placentophagy helped in improving mood stability, increase vitality, improve lactation, accelerate physical recovery and decrease postnatal bleeding $[1,13,14,16]$. This article further 1) review the historical aspects of placental therapy, 2) explain the properties and beneficial nutrients of placenta, and 3) explain the application of placental therapy and its therapeutic effects.

\section{Historical aspects of placental therapy}

Historically, the placenta was recognized as a traditional folk medicine in China and other parts of the world with its vast nutrients and biological active components. In China, Li Shizen's “Compendium of Materia Media" in the sixteenth century documented dried human placenta, also known as " $\mathrm{Zi} \mathrm{He} C h e$ " to increase energy and vitality and for the treatment of impotence, infertility, liver and kidney problems [17]. In Argentina, the Araucanian Indians used dried umbilical cord grinded into powder form for the treatment of the sick child. Furthermore, the Kol tribe in Central India consume placenta to promote reproductive function [15]. Numerous historical occurrences of placentophagy were practiced in many parts of the world; yet there were no documentations and researches on the therapeutic efficacy of the placental extract until research was conducted in 1930s in the Soviet Union.

In the 1930s, Filatov V.P, an ophthalmologist from Soviet Union reported the accelerated regeneration of tissues and the suppression of disease when placental extracts rich in biogenic stimulators were administered into a diseased organism. Injections of placenta were able to activate whole body function and also promote the recovery of diseases [18]. In was followed by administration of human placental extracts in Japan in the 1950s. Thereafter, placental extracts were used in aesthetics and therapeutics anti-aging strategies in countries such as India, Japan, Korea, Thailand and the United States of America [19-23].

\section{Cellular mechanism of placental therapy}

In placental therapy, extracts of placenta containing polydeoxyribonucleotide (PDRN), enzymes, nucleic acids, amino acids, peptides, vitamins, trace elements, minerals and growth factors are normally administered via intramuscular injection $[7,9,19]$. Administered placental extracts are readily absorbed by binding to specific receptors present on the surface of targeted cells followed by stimulating inactive or damaged cells, tissues and organs in the body, thus providing tissue repair and regeneration [24]. A schematic diagram outlining the mechanism of growth factors present in placental extracts triggering the fibroblast cells to produce collagen and provide elasticity to the skin is shown in Figure 1. In addition, placental extracts also exhibit many other therapeutic properties and act as a stimulant for tissue repair, wound healing, immunomodulation, anti-inflammatory, cellular proliferation and tissue regeneration $[9,25,26]$.

\section{Nutrient content and properties of placenta}

The placenta connects the mother and fetus and serves as a transportation vehicle to deliver nutrients principally glucose, amino acids, fatty acids, vitamins and minerals for the growth and development of the fetus [4]. Research findings reported that the nutrients which are delivered via the placenta could be retained after the delivery of the fetus [27]. Previous reports indicated that human placental extracts contain collagen, elastin, laminin, vitamins, trace elements, nucleic acids, amino acids, peptides, cytokines and growth factors $[5,7,16,22,28]$. This review further explains the nucleic acids, amino acids, peptides, vitamins, minerals, trace elements, extracellular matrix components, cytokines and growth factors of placental extracts, as recorded in previous research publications.

\section{Nucleic acids}

Two principal nucleic acids, ribonucleic acid (RNA) and deoxyribonucleic acid (DNA) are present in placenta.

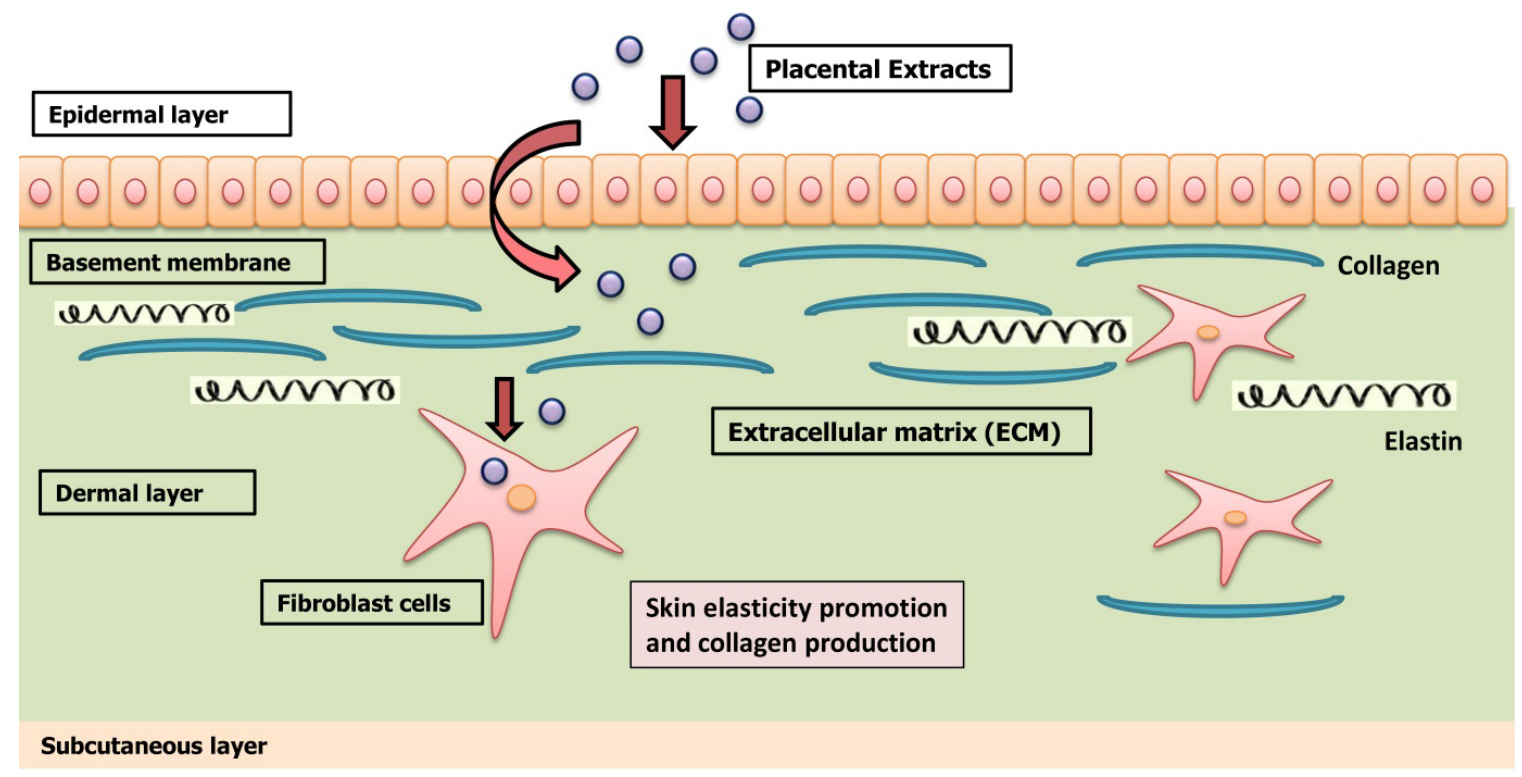

Figure 1. Complex Regional Pain Syndrome Type 1 Relieved by Acupuncture Point Injections with Placental Extract [75]. 
Polydeoxyribonucleotide (PDRN), an active component composed of different lengths of deoxyribonucleotide polymers extracted from placenta activates the salvage pathway for the biosynthesis of nucleosides, nucleotides and nucleic acids [29]. In addition, PDRN were shown to exhibit wound healing function especially for the treatment of ulcers, wounds and scars [28,30].

Since 2003 Stellar Biomolecular Research (Germany) and Stellar Biomolecular Innovations has implemented a cold-enzymatic processing with further nano-filtration of biologically active ingredients for the manufacturing of liquid forms of placental extracts. Nanofiltrates or Eco-Ultra-Filtrates (EUF) of placental extracts possess high bioavailability due to the molecular weight below $10 \mathrm{kDa}$ and linear size of the peptides below $10 \mathrm{~nm}$.

Placental peptides, extracts and growth factors produced under the MF+ brand are currently widely used across 75 countries for management of non-healing wounds, ulcers, diabetic foot syndrome, osteoarthritis, etc.

\section{Amino acids and peptides}

Amino acids symbolize as the key nutrients during intrauterine life [31]. Types of essential and non-essential amino acids present in the placenta include alanine, aspartic acid, arginine, histidine, leucine, lysine, phenylalanine, proline, tyrosine, trytophan, valine [3234]. These amino acids stimulates stimulates fibroblasts production, collagen production and decrease skin pigmentation [35].

Stellar Biomolecular Innovations has included placental peptides to its proprietory formulations for aesthetic skin rejuvenation - SPMCE (skin, placenta, mesenchyme, collagen, elastin). This unique formula provides a complete holistic rejuvenating and revitalizing effect on the skin and can be applied either vie mesotherapy or topically along with various cosmeceutical aesthetic procedures.

It was noted that SPMCE (Nano-peptides and latest peptides range - "Mito Organelles") not only have a lasting aesthetic effect but also have high therapeutic efficacy in management of hypertropic and keloid scars, when administered sublesion.

\section{Vitamins, minerals and trace elements}

Vitamins are vital nutrients which are important in both intermediary and specialized metabolic process to maintain the health and development of organs [36]. A myriad of vitamins, minerals and trace elements were demonstrated in previous reports. Specific vitamin $\mathrm{B}$ binding sites were demonstrated in the placenta followed by the discovery of vitamin $B_{1}, B_{2}, B_{5}, B_{6}, B_{7}, B_{9}, B_{12}$ in placental extracts which play a role in cell metabolism, cell division, cell development and energy production $[7,13]$. Young et al. [37] analysed the minerals and trace elements of encapsulated placental extracts by coupled plasma mass spectrometry and reported the presence of calcium, copper, iron, magnesium, manganese, phosphorus, potassium silicon, sodium and zinc in the extracts. Minerals and trace elements are essential in minute quantities for the normal development of the human body and functioning of the body [38].

\section{Extracellular matrix components}

The extracellular matrix (ECM), present within all tissues and organs, is the largest component in the dermal layer which provides the biochemical network and structural integrity to all surrounding cells. They are comprised of collagens, proteoglycans/ glycosaminoglycans, elastin, fibronectin, laminins and other glycoproteins $[39,40]$. Collagens (type I, III, IV, V, VII, VIII and XVI, XVII), the main component in the ECM provide tensile strength, cell adhesion regulation, tissue development, cellular migration and chemotaxis are present in the human placenta [41]. Placenta is also rich in elastin, which provide elasticity to the skin and recoils to tissues like a spring undergoing repeated stretch $[39,42]$. Besides, fibronectin, important for the maintenance of normal cell morphology, cell migration; and laminin, which play a role in cells attachment, differentiation and tissue survival are also detected in human placental extracts [43-45].

\section{Cytokines and growth factors}

Cytokines and growth factors are a large group of secreted proteins that stimulate intracellular communication to initiate cellular response via specific cell-surface receptors. They act as messengers and transmit intracellular signals through autocrine signalling (act on the same cell that produces the growth factor and responds to it), paracrine signalling (act on the cells that are adjacent to the producer cell) and endocrine signalling (enter to the circulation that travel to distant cells) $[46,47]$. Growth factors are important in regulating and stimulating growth, proliferation, migration and differentiation of cells [48]. Many cytokines, such as granulocyte-colony stimulating factor (G-CSF) and granulocyte-macrophage colony stimulating factor (GM-CSF) are growth factors as they play a role in inducing growth, differentiation and proliferation of cells [49]. Placental extracts are rich in growth factors G-CSF, GM-CSF, EGF, FGF, HGF, IGF, PDGF, TGF, VEGF which show an array of physiological effects ranging from immunomodulation, anti-inflammatory, wound healing, cellular proliferation and regeneration (Table 1) [42,50-52].

Systemically and locally administered placental extracts are commonly used in anti-aging and sports medicine for the management of osteoarthritis and various wear and tear diseases of loco-motor apparatus.

\section{Biological and therapeutic applications of placental extracts}

\section{Anti-inflammatory and anti-oxidant properties}

Administration of placental extracts was shown to exhibit antiinflammatory properties. Amniotic epithelial cells (AEC) and amniotic mesenchymal stromal cells (AMSC) isolated from the amniotic membrane, the innermost layer of the placenta were known to exhibit anti-inflammatory properties [66]. Previous researches by Sur et al. [9] investigated the anti-inflammatory activity of placental extracts by inducing inflammation in the hind paws of Wistar rats with carrageenan, serotonin $(5-\mathrm{HT})$ and prostaglandin $\mathrm{E}_{1}$. Following paw edema inflammation, placental extracts were administered to the rats and paw edema inflammation was reduced significantly.

In addition, placental extracts also served as natural anti-oxidants as they contained superoxide dismutase, catalase and glutathione peroxidase which function in neutralizing free radicals, preventing cellular impairment and disease development [67]. Shinde et al. [68] studied the hydroxyl radical scavenging activity, reducing power assay, nitric oxide scavenging assay and anti-lipid peroxidation of human placental extracts and these extracts provide protection and scavenge against various free radicals and are potential source of natural antioxidants. Besides, previous investigation on placental extracts could significantly reduce nitrite-induced oxidative damage in erythrocytes with ABTS scavenging and chelating abilities [69]. 
Table 1. Major cytokines and growth factors and their respective roles and functions.

\begin{tabular}{|c|c|c|}
\hline $\begin{array}{l}\text { Classification of } \\
\text { growth factors }\end{array}$ & Functions & Source \\
\hline \multicolumn{3}{|l|}{ Cytokines } \\
\hline Interleukin-1 (IL-1) & $\begin{array}{l}\text { Promotes the regulation } \\
\text { of immune system the } \\
\text { production of T, B and NK } \\
\text { cells }\end{array}$ & {$[5]$} \\
\hline Interleukin-2 (IL-2) & $\begin{array}{l}\text { Promotes and regulates } \\
\text { the activity and growth of } \\
\text { T cells, central regulator } \\
\text { or mediator of immune } \\
\text { response }\end{array}$ & [53] \\
\hline Interleukin-4 (IL-4) & $\begin{array}{l}\text { Eradicate extracellular } \\
\text { pathogens and regulate } \\
\text { antibody production, } \\
\text { involved in the } \\
\text { differentiation from Th0 into } \\
\text { Th1 and Th2 cells }\end{array}$ & {$[54-56]$} \\
\hline \multicolumn{3}{|l|}{ Growth factors } \\
\hline $\begin{array}{l}\text { Granulocyte-colony } \\
\text { stimulating factor (G-CSF) }\end{array}$ & $\begin{array}{l}\text { Regulates cell cycle } \\
\text { activation, survival of } \\
\text { the myeloid lineage, } \\
\text { mediates the proliferation, } \\
\text { differentiation and survival } \\
\text { of neutrophil progenitors }\end{array}$ & {$[52,57]$} \\
\hline $\begin{array}{l}\text { Granulocyte-macrophage } \\
\text { colony stimulating factor } \\
\text { (GM-CSF) }\end{array}$ & $\begin{array}{l}\text { Proliferation of macrophage } \\
\text { progenitors, promotes the } \\
\text { maturation of dendritic cells }\end{array}$ & {$[50]$} \\
\hline $\begin{array}{l}\text { Epidermal growth factor } \\
\text { (EGF) }\end{array}$ & $\begin{array}{l}\text { Stimulates cell migration } \\
\text { and proliferation for wound } \\
\text { and skin repair }\end{array}$ & {$[24,58]$} \\
\hline $\begin{array}{l}\text { Fibroblast growth factor } \\
\text { (FGF) }\end{array}$ & $\begin{array}{l}\text { Promotes the growth of } \\
\text { fibroblast cells, induce } \\
\text { endothelial cell migration } \\
\text { for tissue regeneration and } \\
\text { wound healing }\end{array}$ & {$[59,60]$} \\
\hline $\begin{array}{l}\text { Hepatocyte growth factor } \\
\text { (HGF) }\end{array}$ & $\begin{array}{l}\text { Stimulates the production } \\
\text { of liver cells and also } \\
\text { renal tubular epithelial } \\
\text { cell, acts as a mitogen for } \\
\text { human keratinocytes and } \\
\text { melanocytes. }\end{array}$ & {$[51]$} \\
\hline $\begin{array}{l}\text { Insulin-like growth factor } \\
\text { (IGF) }\end{array}$ & $\begin{array}{l}\text { Regulates feto-placental } \\
\text { growth throughout gestation, } \\
\text { promotes the growth of } \\
\text { muscle cells and cells } \\
\text { proliferation }\end{array}$ & {$[61]$} \\
\hline $\begin{array}{l}\text { Platelet-derived growth } \\
\text { factor (PDGF) }\end{array}$ & $\begin{array}{l}\text { Promotes cell differentiation, } \\
\text { proliferation, migration and } \\
\text { survival in different organs, } \\
\text { promotes tissue repair and } \\
\text { wound healing process }\end{array}$ & {$[62,63]$} \\
\hline $\begin{array}{l}\text { Transforming growth factor } \\
\text { (TGF) }\end{array}$ & $\begin{array}{l}\text { Promotes proliferation and } \\
\text { differentiation of epithelial } \\
\text { cells and tissue remodelling }\end{array}$ & {$[64]$} \\
\hline $\begin{array}{l}\text { Vascular endothelial growth } \\
\text { factor (VEGF) }\end{array}$ & $\begin{array}{l}\text { Regulation of angiogenesis, } \\
\text { vascular development, } \\
\text { hematopoietic development, } \\
\text { neuroprotection }\end{array}$ & {$[42,65]$} \\
\hline
\end{tabular}

\section{Anti-microbial properties}

The placenta provides an immunological balancing environment to defend against invading microorganisms during pregnancy. Histones $\mathrm{H} 2 \mathrm{~A}$ and $\mathrm{H} 2 \mathrm{~B}$ proteins isolated from the fetal membrane of the placenta served as an endotoxin-neutralizing barrier and provide protection against penetration by microorganisms [70]. Chakraborty \& Bhattacharyya [19] studied the role of placental extracts on the growth of different microbes. Placental extracts could inhibit the growth of different types of bacteria (Escherichia coli, Staphylococcus aureus) and fungi (Saccharomyces cerevisiae, Kluyveromyces fragilis, Candida albicans). Furthermore, it has an inhibitory role against clinically isolated E. coli strains isolated from urine and blood culture and Pseudomonas aeruginosa isolated from pus culture indicated that placental extracts exhibit bacteriostatic and fungistatic activities.

\section{Wound healing properties}

The usage of placental extracts for burn injuries, chronic wounds and post-surgical dressings has already been applied as a traditional medicine in many countries ranging from China, Korea and Japan and many more [8].

Burgos, Herd \& Bennett [71] extracted growth factors extracted from human placentas for the treatment of chronic varicose ulcers in eighteen patients. These patients were randomly allocated to receive dressings containing or not containing the growth factors for a period of 48 hours. Results showed patients treated with placental growth factors enhanced the formation of epithelial and granulation tissue and accelerated the wound healing process.

Placental extracts were shown to be effective in healing diabetic wounds in a study conducted by Navadiya et al. [26]. This study compared the effectiveness of topical placental extracts dressings versus the povidone iodine dressings in various patients with diabetic wounds. Placenta wound dressings could significantly accelerate the rate of wound healing when compared to povidone iodine dressings as it contained amino acids, vitamins and nucleotides with accelerated wound healing recovery of seven to ten days. Consequently, Fatemeh et al. [72] tested the burn wound healing activity using placenta membrane, or placenta membrane impregnated with honey or SSD by creating deep partial thickness burn on sixty four Wistar rats. Placenta was chosen as it contained various growth factors including FGF, EGF, TGF- $\beta$ and IL- 1 which enhance the reepithelialisation and reconstruction of the skin and as a rapid physiological wound healer. All burn wounds applied with placenta membrane showed accelerated wound coverage and reconstruction of partial thickness burns when compared to the placebo group indicating that the placenta membrane could be applied as a dressing for wounds.

\section{Hair growth promotion}

Alopecia is a constantly increasing problem attributable to hormones, genetic factors, autoimmune diseases, medications and stress which alter the hair follicle cycle and causes hair loss. Previous report by Seo et al. [73] showed the effectiveness of placental extracts in hair growth promotion. The hair growth of depilated C57BL/6 mice was investigated by applying human placental extracts topically once a day for fifteen days consecutively. Gross examination and histological analysis showed the placental extracts marked increased hair regrowth and also increased the expression of FGF-7, which play pivotal roles in maintain the anagen phase and the cellular proliferation of hair follicles suggesting that it may be a good candidate for the treatment of alopecia.

This quality of placental extracts allows its successful application in treatment of hair loss. European Wellness Centers International Group has employed mesotherapy with MF+ Placental extracts in the scalp area as a part of the therapies that promote hair growth in male individuals.

\section{Reduces and relieves pain}

Consumption of placenta after postpartum were known to provide natural pain relief after labour [16]. In the review of experimental study the effectiveness of placental extracts on pain management, DiPirro 
and Kristal [74] reported the ingestion of placenta produces a dramatic enhancement of centrally mediated opioid antinociception. Besides, Cho \& Park [75] conducted a research on the effectiveness of placental extracts in treating patients suffering from complex regional pain syndrome (CRPS) - an inflammation-associated disorder characterized by spontaneous pain, swelling, changing of skin colour and restricted movement. Patients with CRPS showed remarkable amelioration after receiving injections of placental extract into acupuncture points BL23, BL24, BL25 and LR4. All patients showed complete pain relief, swelling reduction, redness disappearance and articular movement restoration.

\section{Improves health and energy}

Administration of placental extracts was shown to improve general health and well-being. Placenta contains iron which replenishes the iron level in the body to eradicate fatigue and provides energy [27]. Human placenta are commonly used in traditional chinese medicine for the treatment of chronic fatigue syndrome [76]. A survey on 189 females on maternal placentophagy was investigated. $26 \%$ of the women reported an increased energy and decreased fatigue, $40 \%$ reported an improved mood and 15\% reported an improved lactation after the consumption of placenta [16].

\section{Integrative biological treatment by placental therapy}

There has been much progress of the therapeutics uses of placental extracts since the early 1900s. Since 1992, MFIII brand was famed as the first cellular therapy oral supplements made from premium sheep placental extracts (http://mf3swiss.com/). In addition, SBI Research \& Development unit (Germany) has released sheep or rabbit placenta therapeutics range and produced under MF+ brand (http://www.mfplus.com/) which are known as "Fresh and Pure Range - HP Placenta", "Nano Organo Peptides (placenta)" and "Mito Organelles (placenta)". All of these products were manufactured by cryoporosis ${ }^{\mathrm{TM}}$ extraction and heatless sterilization, a unique patented method which could retain all beneficial bioactive components and nutrients of the placenta for well-being, health restoration and complete body rejuvenation.

\section{Conclusion}

Integrative biological medicine plays an important role for restoration and the management of health and wellness. Placental extracts contain active ingredients remain essential in the field of rejuvenation, revitalisation and restore youth and vitality by slowing down the aging processes. It is deemed as an effective therapeutic agent with potent regenerative properties in human tissues.

\section{Acknowledgements}

The authors would like to thank SBI (Stellar Biomolecular Innovations) research and development unit (http://sbi-europe.com) for supporting this research.

\section{References}

1. Schuette SA, Brown KM, Cuthbert DA, Coyle CW, Wisner KL, et al. (2017) Perspectives from patients and healthcare providers on the practice of maternal placentophagy. J Altern Complement Med 23: 60-67. [Crossref]

2. Kelly RW (1992) Nutrition and placental development. Proceedings of the Nutrition Society of Australia 17: 203-210.

3. Longo LD, Reynolds LP (2010) Some historical aspects of understanding placental development, structure and function. Int J Dev Biol 54: 237-255. [Crossref]

4. Donnelly L (2016) Functions of the placenta. Anaesthesia and Intensive Care Medicine 17: 349-353.

5. Nikolaos V, Charalampos G, Dimitrios Z, Nikolaos V (2015) The endocrine and paracrine role of placental cytokines, growth factors and peptides. Official $J$ Hellinic Society of Obstet Gynecol 14: 33-38.
6. Latendresse G, Founds S (2015) The Fascinating and Complex Role of the Placenta in Pregnancy and Fetal Well-being. J Midwifery Womens Health 60: 360-370. [Crossref]

7. Biswas TK, Auddy B, Bhattacharya NP, Bhattacharya S, Mukherjee B (2001) Wound healing activity of human placenta.pdf. Acta Pharmacol Sin 12: 1113-1116.

8. Chakraborty PD, Bhattacharyya D (2012) Aqueous Extract of Human Placenta as a Therapeutic Agent. In Recent Advances in Research on the Human Placenta. Rijeka, Croatia: InTech pp. 77-92.

9. Sur TK, Biswas TK, Ali L, Mukherjee B (2003) Anti-inflammatory and anti-platele aggregation activity of human placental extract. Acta Pharmacol Sin 2: 187-192. [Crossref]

10. Majeed AF, Shalal MS, Mohammed TR (2012) Histology of ovine placenta during gestation periods. Kufa J Veterinary Med Sciences 3: 838-847.

11. Griffiths SK, Campbell JP (2015) Placental structure, function and drug transfer Continuing Education Anaesthesia, Crit Care Pain 15: 84-89.

12. King BF (1992) Comparative studies of structure and function in mammalian placentas with special reference to maternal-fetal transfer of iron comparative studies of structure and function in mammalian placentas with special reference to maternal-fetal transfer of Iron. American Zoologist 32: 331-342.

13. Marraccini ME, Gorman KS (2015) Exploring Placentophagy in Humans: Problems and Recommendations. J Midwifery Womens Health 60: 371-379. [Crossref]

14. Young SM, Benyshek DC (2010) In search of human placentophagy?: A cross- cultural survey of human placenta consumption, disposal practices, and cultural beliefs. Ecol Food Nutr 49: 467-484. [Crossref]

15. Ober WB (1979) Notes on placentophagy. Bull N Y Acad Med 55: 591-599. [Crossref]

16. Selander J, Cantor A, Young SM, Benyshek DC (2013) Human maternal placentophagy: a survey of self-reported motivations and experiences associated with placenta consumption. Ecol Food Nutr 52: 93-115. [Crossref]

17. Shizhen L, Xiwen L (1593) In: Kaimin H, Yousheng C (Eds.), Compendium of materia medica: bencao gangmu. Beijing, China: Foreign Language Press pp 4182-4186.

18. Filatov VP (1944) Tissue Therapy in Ophthalmology. Am Rev Soviet Med 2: 53-66.

19. Chakraborty PD, Bhattacharyya D (2005). In vitro growth inhibition of microbes by human placental extract. Curr Sci 88: 1745-1749.

20. Kawakatsu M, Urata Y, Goto S, Ono Y, Li T (2013) Placental extract protects bone marrow-derived stem / progenitor cells against radiation injury through antiinflammatory activity. $J$ Rad Res 54: 268-276. [Crossref]

21. Marleau AM, Mcdonald G, Koropatnick J, Chen C, Koos D (2012) Reduction of Tumorigenicity by Placental Extracts. Anticancer Res 32: 1153-1161. [Crossref]

22. Park SY, Phark S, Lee M, Lim JY, Sul D (2010) Anti-oxidative and anti-inflammatory activities of placental extracts in benzo [a] pyrene-exposed rats. Placenta 31: 873-879. [Crossref]

23. Poompruek P, Boonmongkon P, Guadamuz TE (2014) 'For me ... it's a miracle' Injecting beauty among kathoeis in a provincial Thai city. Int J Drug Policy 25: 798803. [Crossref]

24. Mitchell AC, Briquez PS, Hubbell JA, Cochran JR (2016) Engineering growth factors for regenerative medicine applications. Acta Biomaterialia 30: 1-12. [Crossref]

25. Kong M, Park SB (2012) Effect of human placental extract on health status in elderly koreans. Evidence-Based Complementary Alt Med: 1-5.

26. Navadiya SK, Vaghani YL, Patel MP (2012) Study of topical placental extract versus povidone iodine and saline dressing in various diabetic wounds. Nat J Med Res 2 411-413.

27. Beacock M (2012) Does eating placenta offer postpartum health benefits? British $J$ Midwifery 20: 464-469.

28. Noh TK, Chung BY, Kim SY, Lee MH, Kim MJ, et al. (2016) Novel AntiMelanogenesis Properties of Polydeoxyribonucleotide, a Popular Wound Healing Booster. Int J Mol Sci 17: 1-11. [Crossref]

29. Sini P, Denti A, Cattarini G, Daglio M, Tira ME, et al (1999) Effect of polydeoxyribonucleotides on human fibroblasts in primary culture. Cell Biochem Funct 17: 107-114. [Crossref]

30. Tonello G, Daglio M, Zaccarelli N, Sottofattori E, Mazzei M, et al. (1996) Characterization and quantitation of the active polynucleotide fraction (PDRN) from human placenta, a tissue repair stimulating agent. J Pharm Biomed Anal 14: 15551560. [Crossref] 
31. Cetin I (2001) Amino acid interconversions in the fetal-placental unit: the animal model and human studies in vivo. Pediatr Res 49: 148-154. [Crossref]

32. Harding VJ, Fort CA (1918) Amino acids of placenta. J Biol Chem 35: 29-41.

33. Nair B, Elmore AR; Cosmetic Ingredient Review Expert panel (2002) Final report on the safety assessment of human placental protein, hydrolyzed human placental protein, human placental enzymes, human placental lipids, human umbilical extract, placental protein, hydrolyzed placental protein, placental enzymes, placental lipids, and umbilical extract. Int J Toxicol 21 Suppl 1: 81-91. [Crossref]

34. Philipps AF, Holzman IR, Teng C, Battaglia FC (1978) Tissue concentrations of free amino acids in term human placentas. Am J Obstet Gynecol 131: 881-887. [Crossref]

35. Lupo MP, Cole AL (2007) Cosmeceutical peptides. Dermatol Ther 20: 343349. [Crossref]

36. Campbell I (2014) Macronutrients, minerals, vitamins and energy. Anaesthesia Intensive Care Med 15: 344-349.

37. Young SM, Gryder LK, David WB, Teng Y, Gerstenberger S, et al. (2016) Human placenta processed for encapsulation contains modest concentrations of 14 trace minerals and elements. Nutr Res 36: 872-878. [Crossref]

38. Pathak P, Kapil U (2004) Role of trace elements zinc, copper and magnesium during pregnancy and its outcome. Indian J Pediatr 71: 1003-1005. [Crossref]

39. Frantz C, Stewart KM, Weaver VM (2010) The extracellular matrix at a glance. J Cell Sci 123: 4195-4200. [Crossref]

40. Theocharis AD, Skandalis SS, Gialeli C, Karamanos NK (2016) Extracellular matrix structure. Adv Drug Deliv Rev 97: 4-27. [Crossref]

41. Niyibizis C, Fietzeks PP, Van Der Rest M (1984) Human Placenta Type V Collagens. J Biol Chem 2: 14170-14174. [Crossref]

42. Choi JS, Kim JD, Yoon HS, Cho YW (2013) Full-thickness skin wound healing using human placenta-derived extracellular matrix containing bioactive molecules. Tissue Eng Part A 19: 329-339. [Crossref]

43. Brown JC, Mann K, Wiedemann H, Timpl R (1993) Structure and binding properties of collagen type XIV isolated from human placenta. J Cell Biol 120: 557-567. [Crossref]

44. Chakraborty PD, Bhattacharyya D (2005) Isolation of fibronectin type III like peptide from human placental extract used as wound healer. J Chromatogr B Analyt Technol Biomed Life Sci 818: 67-73. [Crossref]

45. Colognato H, Yurchenco PD (2000) Form and function: The laminin family of heterotrimers. Dev Dyn 218: 213-234. [Crossref]

46. Leonard WJ, Lin JX (2000) Cytokine receptor signaling pathways. J Allergy Clin Immunol 105: 877-888. [Crossref]

47. Traversa B, Sussman G (2001) The role of growth factors, cytokines and proteases in wound management. Prim Intention 9: 161-167.

48. Barrientos S, Stojadinovic O, Golinko MS, Brem H, Tomic-Canic M (2008) Growth factors and cytokines in wound healing. Wound Repair Regen 16: 585-601. [Crossref]

49. Guzeloglu-Kayisli O, Kayisli UA, Taylor HS (2011) The Role of Growth Factors and Cytokines during Implantation: Endocrine and Paracrine Interactions. Semin Reprod Med 27: 62-79. [Crossref]

50. Cukrová V, Hrkal Z (1987) Purification and characterization of granulocytemacrophage colony stimulating factor from human placenta. J Chromatogr 413: 242246. [Crossref]

51. Horibe N, Okamoto T, Itakura A, Nakanishi T, Suzuki T, et al. (1995) Levels of hepatocyte growth factor in maternal serum and amniotic fluid. Am J Obstet Gynecol 173: 937-942. [Crossref]

52. Uzumaki H, Okabe T, Sasaki N, Hagiwara K, Takaku F, et al. (1989) Identification and characterization of receptors for granulocyte colony-stimulating factor on human placenta and trophoblastic cells. Proc Natl Acad Sci U S A 86: 9323-9326. [Crossref]

53. Boehm KD, Kelley MF, Ilan J, Ilan J (1989) The interleukin 2 gene is expressed in the syncytiotrophoblast of the human placenta. Proc Natl Acad Sci U S A 86: 656660. [Crossref]

54. Abehsira-Amar O, Gibert M, Joliy M, Thèze J, Jankovic DL (1992) IL-4 plays a dominant role in the differential development of Tho into Th1 and Th2 cells. $J$ Immunol 148: 3820-3829. [Crossref]

55. Abehsira-Amar O, Gibert M, Joliy M, Thèze J, Jankovic DL (1992) IL-4 plays a dominant role in the differential development of Tho into Th1 and Th2 cells. $J$ Immunol 148: 3820-3829. [Crossref]
56. de Moraes-Pinto MI, Vince GS, Flanagan BF, Hart CA, Johnson PM (1997) Localization of IL-4 and IL-4 receptors in the human term placenta, decidua and amniochorionic membranes. Immunology 90: 87-94. [Crossref]

57. Whitcomb BW, Schisterman EF, Luo X, Chegini N (2009) Maternal serum granulocyte colony-stimulating factor levels and spontaneous preterm birth. $J$ Womens Health (Larchmt) 18: 73-78. [Crossref]

58. Silini AR, Cargnoni A, Magatti M, Pianta S, Parolini O (2015) The long path of human placenta, and its derivatives, in regenerative medicine. Front Bioeng Biotechnol 162 : 1-16. [Crossref]

59. Anteby EY, Natanson-yaron S, Hamani Y, Ariel I, Yagel S (2005) Fibroblast growth factor-10 and fibroblast growth factor receptors 1-4: expression and peptide localization in human decidua and placenta. Eur J Obstet Gynecol 119: 27-35. [Crossref]

60. Li X, Wang C, Xiao J, McKeehan WL, Wang F (2016) Fibroblast growth factors, old kids on the new block. Semin Cell Dev Biol 53: 155-167. [Crossref]

61. Fowden AL (2003) The Insulin-like Growth Factors and feto-placental Growth Placenta: 803-812. [Crossref]

62. Chhabra A, Lechner AJ, Ueno M, Acharya A, Van Handel B, et al. (2012) Trophoblasts regulate the placental hematopoietic niche through PDGF-B signaling. Dev Cell 22 651-659. [Crossref]

63. Demidova-Rice TN, Hamblin MR, Herman IM (2012) Acute and impaired wound healing: pathophysiology and current methods for drug delivery, part 1: normal and chronic wounds: biology, causes, and approaches to care. Adv Skin Wound Care 25 304-314. [Crossref]

64. Jones, R. L., Stoikos, C., Findlay, J. K., \& Salamonsen, L. A. (2006). TGF-B superfamily expression and actions in the endometrium and placenta. Reproduction 132: 217-232. [Crossref]

65. Andrae J, Gallini R, Betsholtz C (2008) Role of platelet-derived growth factors in physiology and medicine. Genes Dev 22: 1276-1312. [Crossref]

66. Manuelpillai U, Moodley Y, Borlongan CV, Parolini O (2011) Amniotic membrane and amniotic cells: potential therapeutic tools to combat tissue inflammation and fibrosis? Placenta 32 Suppl 4: S320-325. [Crossref]

67. Rozanova SL, Naumenko YI, Nardid EO (2015) Influence of low temperature storage and ultrasonic treatment of placenta on its extracts antioxidant properties. Problems Cryobiol Cryomed 25: 255-266.

68. Shinde V, Dhalwal K, Paradkar AR, Mahadik KR, Kadam SS, et al. (2006) Evaluation of in-vitro antioxidant activity of human placental extract. Pharmacol Online 179: $172-179$.

69. Rozanova S (2014) Antioxidant properties of extracts derived from placentae of different gestation terms. Oxidants Antioxidants Med Sci 3: 181.

70. Kim HS, Cho JH, Park HW, Yoon H, Kim MS, et al. (2002) Endotoxin-neutralizing antimicrobial proteins of the human placenta. J Immunol 168: 2356-2364. [Crossref]

71. Burgos H, Herd A, Bennett JP (1989) Placental angiogenic and growth factors in the treatment of chronic varicose ulcers: preliminary communication. J R Soc Med 82: 598599. [Crossref]

72. Fatemeh SR, Beheshti A, Zangivand AA, Shafigh Y (2015) The effect of honeyimpregnated human placenta membrane on burn wound healing in rat. Compar Clin Pathol 24: 263-268.

73. Seo TB, Han IS, Yoon JH, Seol IC, Kim YS, et al. (2006) Growth-promoting activity of Hominis Placenta extract on regenerating sciatic nerve. Acta Pharmacol Sin 27: 5058. [Crossref]

74. DiPirro JM, Kristal MB (2004) Placenta ingestion by rats enhances delta- and kappaopioid antinociception, but suppresses mu-opioid antinociception. Brain Res 1014: 22 33. [Crossref]

75. Cho TH, Park KM (2014) Complex regional pain syndrome type 1 relieved by acupuncture point injections with placental extract. $J$ Acupunct Meridian Stud 7: 155 158. [Crossref]

76. Chen R, Moriya J, Yamakawa JI, Takahashi T, Kanda T (2010) Traditional chinese medicine for chronic fatigue syndrome. Evid Based Complement Alternat Med 7: 3-10. [Crossref]

Copyright: (C2017 Pan SY. This is an open-access article distributed under the terms of the Creative Commons Attribution License, which permits unrestricted use, distribution, and reproduction in any medium, provided the original author and source are credited. 